\title{
HIV-1 infection: Is it time to reconsider our concepts?
}

\author{
ELIAS KRAMBOVITIS ${ }^{1,2}$ and DEMETRIOS A. SPANDIDOS ${ }^{3}$

\begin{abstract}
${ }^{1}$ Department of Applied Biochemistry and Immunology, Institute of Molecular Biology and Biotechnology, Vassilika Vouton, Heraklion, Crete; ${ }^{2}$ Department of Veterinary Medicine, University of Thessaly, Karditsa,
\end{abstract} \\ Thessaly; ${ }^{3}$ Department of Virology, Medical School, University of Crete, Heraklion, Crete, Greece
}

Received April 12, 2006; Accepted May 15, 2006

\begin{abstract}
The long asymptomatic phase of HIV infection is critical in the progression to AIDS. It probably reflects an ancestral relationship with lentiviruses stemming from the primate-simian immunodeficiency virus evolutionary pathway leading to an idiosyncratic immune tolerance, which needs to be understood if effective vaccines are to be rationally designed. The majority of $\mathrm{CD}^{+}{ }^{+} \mathrm{T}$ cells that die due to HIV-1 in the asymptomatic phase are not infected with the virus. Transmission of the predominant HIV-1 R5 variants to T cells is mediated by infected monocyte-derived macrophages. The two cell populations come into intimate contact mainly in the lymph nodes during antigen presentation where there is also active viral replication. We propose that HIV exploits antigen presentation to access target $\mathrm{T}$ cells and evade immune surveillance. This is achieved at the assembly point of an immunological synapse between an antigen presenting, HIV-1infected macrophage and a responding effector/memory $\mathrm{CD}^{+} \mathrm{T}$ cell. Viral envelope gp120 glycoproteins proximal to MHC II molecules cross-link with T cell CD4 molecules, thus establishing a supra molecular immuno-viral synapse. The interaction results in conformational changes of gp120 exposing its V3 domain. Ionic interaction of this domain with the synapse-recruited chemokine receptor CCR5 dimerizes the receptor triggering intracellular signals that contribute to $\mathrm{T}$ cell receptor transactivation pathways and subsequent enhancement of T cell activation. HIV-downregulated MHC II gives weak immune complexes. Disruption of the immunoviral synapse before completion of cell entry is a frequent outcome condemning the responding $\mathrm{T}$ cell to a premature activation-induced $\mathrm{T}$ cell death. Information on the assembly, mechanistic and functional interactions at the immuno-viral synapses may well assist in elucidating new strategies to combat HIV infection.
\end{abstract}

Correspondence to: Professor E. Krambovitis, Department of Applied Biochemistry and Immunology, IMBB, FORTH, P.O. box 1527, Heraklion 711 10, Crete, Greece

E-mail: krambo@imbb.forth.gr

Key words: HIV, AIDS, CD4+ T cells

\section{Contents}

1. Introduction

2. Is AIDS associated with the evolution of common viral ancestors to HIV?

3. AIDS: a cytopathic viral disease or an immune dysfunction caused by the presence of HIV-1?

4. The antigen activation $\mathrm{CD}^{+}{ }^{+} \mathrm{T}$ cell death model

5. HIV-1 cell attachment and entry process

6. Is HIV-1 attachment facilitated by immuno-viral synapses?

7. Proposed theoretical model of R5 HIV-1 cell attachment and concluding remarks

\section{Introduction}

Two decades have passed since the human immunodeficiency virus-1 (HIV-1) was isolated and identified as the causative agent of the acquired immunodeficiency syndrome (AIDS) $(1,2)$. HIV-1 infection is characterized by the progressive depletion of $\mathrm{CD}^{+} \mathrm{T}$ cells that results in $\operatorname{AIDS}(3,4)$. The prevailing theory for most of this period was that the virus directly infected and killed CD4 ${ }^{+} \mathrm{T}$ cells. AIDS was, therefore, addressed as a cytopathic viral infection and research efforts were focused on deciphering the precise biology of the virus within the host cell. Indeed, as a result of this research activity, nucleoside and non-nucleoside analogue reverse transcriptase inhibitors, protease inhibitors and powerful combinations of these for highly active anti-retroviral therapy (HAART) became the drugs of choice for AIDS patients. Despite considerable advances, HIV-1 pathogenesis remains elusive. Although AIDS may be treatable with satisfactory prognosis, it remains incurable, accounting for 4.9 million new infections and 3 million deaths in 2005 alone (December 2005 report, UNAIDS). Coupled to this, high toxicity of the drugs, and drug-resistance related to the diversity of rapidly mutating HIV-1 viruses necessitate meticulous treatment and management of HIV-1-infected patients (5). This is an impossible task in the prevailing areas of Asia and Africa. Eradication of HIV infection together with prevention must, therefore, be the ultimate goal. The recently-reported and encouraging in vivo results from the use of valproic acid with HAART (6) may be a step in that direction, but we still need to better understand the whole repertoire of the viral escape.

In recent years research attention has shifted towards immune-based therapies such as the use of cytokines, vaccines 
including DNA-type vectors, and blockers of cell activation. No data from these approaches have so far suggested clinical benefit, either alone or combined with antiretroviral drugs (5). Generation of new knowledge relating to HIV-1 pathogenesis is clearly required if alternative intervention strategies or vaccines are to be successful. Consequently, we have to reconsider and revise our concepts on HIV-1/AIDS by readdressing some fundamental questions.

\section{Is AIDS associated with the evolution of common viral ancestors to HIV?}

The emergence of the virus as a human infection is estimated from back calculations of the evolutionary rate of the virus and from the oldest known strain isolated from a 1951 sample (7) to have commenced at around $1930(8,9)$. This hostparasite adaptation period is far too short in Darwinian evolutionary terms to explain the clinical latency of HIV-1 infection. Either a launch of a very violent immune response would have been expected or a kind of rapid attenuation, which has not been observed since its discovery over 20 years ago. As neither of these conditions appear to have occured, an alternative explanation may be that the Man-HIV relationship has much older roots stemming perhaps from the primatesimian immunodeficiency virus (SIV) evolutionary pathway (10), thus reflecting a kind of human ancestral adaptation that has led to an idiosyncratic immune tolerance. Idiosyncratic tolerance could be defined as the cellular responses to HIV that persist throughout the infection but fail to be effective. This speculative hypothesis may eventually be a key consideration in the dynamics of HIV-1 infection. If a protective vaccine is to be developed, it must be capable of coping with both the natural genetic diversity of HIV-1 (11), and at the same time of surpassing this form of tolerance in order to evoke a strong and effective immune response.

\section{AIDS: a cytopathic viral disease or an immune dys- function caused by the presence of HIV-1?}

AIDS is viewed as an immune dysregulation syndrome caused by the presence of HIV-1 (12). Therefore, we must identify and address the immune mechanism impaired. The course of HIV-1 infection is marked by three stages: i) an early, acute infection stage lasting a few weeks with rapidly increasing viraemia and sharp depletion of $\mathrm{CD}^{+}{ }^{+} \mathrm{T}$ cells; ii) a chronic asymptomatic phase characterized by a rapid recovery of circulating $\mathrm{CD}^{+} \mathrm{T}$ cells and diminishing viral loads followed by a very gradual decline of these cells lasting, on average, approximately 10-12 years; and iii) onset of AIDS when the $\mathrm{CD}^{+} \mathrm{T}$ cell subset reaches a critical minimum level (13). Depletion of these immune cells leads to increased sensitivity of the patient to opportunistic and chronic infections and to oncogenesis (14).

The cause of the depletion is still under debate. The first and last stages of the infection are governed by the cytopathic effects of the virus. It is evident, however, that during the second, asymptomatic phase, immune function events associated with virus-cell interactions are critical to the AIDS outcome. The introduction of kinetic parameters in HIV infection studies, including viral and infected cell half-lives, has convincingly shown that the replenishment rate of circulating $\mathrm{CD}^{+} \mathrm{T}$ cells is far greater than the turnover of infectious virus particles. The cytopathicity model alone, therefore, cannot explain the overall depletion of $\mathrm{CD}^{+} \mathrm{T}$ cells (15) and the progression to AIDS. Considering the natural evolution of HIV, it can be speculated that the cytopathic effects of the first and third stages reflect the recent definitive adaptation of this lentivirus to man. The idiosyncratic immune tolerance during the long second phase, and the resultant chronic immunodeficiency probably testify also to an ancestral relationship. Elucidating the precise mechanisms in the second phase with which the virus deregulates immune functions without infecting those cells may be critical in designing novel strategies.

\section{The antigen activation induced $\mathrm{CD4}^{+} \mathrm{T}$ cell death model}

Several immunological theories on HIV pathogenesis were inevitably formulated, including impairment of peripheral homeostatic functions by chronic immune activation $(16,17)$. Although these concepts are generally consistent with the overall clinical observations, they need to be described in basic immune mechanisms, and the 'chronic' activation and death of $\mathrm{CD}^{+} \mathrm{T}$ cells must be explained in terms of specific cellular and molecular interactions. The immune activation is not generalized, i.e. viral components do not appear to have mitogenic or superantigen-type properties. HIV-1 does not greatly affect the $\mathrm{CD} 8^{+} \mathrm{T}$ cell subset either, although as a virus it would have been expected to do so. Strikingly, it chiefly affects the $\mathrm{CD}^{+} \mathrm{T}$ cell subpopulation. The evidence is overwhelming (reviewed in ref. 18) that the presence of HIV alters the physiological process of activation-induced cell death (19) affecting predominantly uninfected CD4 ${ }^{+} \mathrm{T}$ cells (20). The envelope glycoproteins, gp120 and gp41, have been consistently implicated in this respect. Gp120 mediates viral entry by binding to target cell CD4 and chemokine receptors. After gp120-CD4/chemokine receptor binding, gp41 mediates fusion of the viral and host cell membranes $(21,22)$. Synthetic peptides that inhibit this fusion process have successfully completed clinical trials and are now available as new therapeutic agents (comprehensively reviewed in refs. 23-29).

The interaction between gp120 and its primary receptor CD4 does not directly or exclusively alter the fate of the host cell. The signal transduction that leads the host cell to death seems to be governed mainly by the interaction of gp120 with the co-receptors, CCR5 and CXCR4 $(30,31)$, which belong to the seven-transmembrane G-protein coupled receptor family. HIV-1 variants referred to as R5 strains (32), responsible for host-to-host transmission and predominant at the asymptomatic phase, utilize CCR5 as co-receptor. CCR5 regulates trafficking and effector functions of memory/effector $\left(\mathrm{CD} 45 \mathrm{RO}^{+}\right) \mathrm{T}$ cells and macrophages. The gp120-CCR5 interaction consequently affects the memory/effector $\mathrm{CD}^{+}{ }^{+} \mathrm{T}$ cell subpopulation, as indicated in ex vivo studies $(33,34)$. It is evident that gp120 is involved in binding to target cells and at the same time it is the most potent inducer of cell apoptosis in uninfected memory/ effector $\mathrm{CD}^{+} \mathrm{T}$ cells $(35,36)$. This appears to be a contradiction in terms which we attempt to address with our proposed theoretical model. 
Depletion of CD4 ${ }^{+} \mathrm{T}$ cells, particularly the memory/effector subset, is not necessarily the cytopathic result of HIV infection, but it may be the inevitable outcome of immune dysfunction. $\mathrm{CD}^{+} \mathrm{T}$ cells interact with professional antigen-presenting cells and modulate the immune response via cytokine secretion and proliferation. We must consider the function of these target cells and how gp120 alters their behavior. This suggests that the observed immune dysregulation by HIV-1 must be related to the antigen presentation mechanism. The HIV-1 R5 variants are characterized by their macrophage-tropic phenotype. The role of macrophages in HIV pathogenesis was only belatedly appreciated despite convincing evidence for their involvement in $\mathrm{CD}^{+}{ }^{+} \mathrm{T}$ cell death $(19,35,36)$. HIV-1-infected macrophages remain functional, although their ability to present antigens is greatly reduced (37). Considering these observations, it was demonstrated by using synthetic peptides from the semi-conserved principal neutralizing determinant (PND) of the gp120 V3 domain, and presented on the surface of monocyte-derived macrophages, that they deliver a V3specific signal of activation-apoptosis to tetanus memory/ effector $\mathrm{CD}^{+} \mathrm{T}$ cells during antigen presentation of tetanus toxin $(38,39)$. The V3 interacted, at least, with the amino terminal of CCR5 $(38,40,41)$. A hypothesis was proposed that signal transduction from the V3-CCR5 interaction was regulated by the cationic strength of the V3 domain rather than by specific conformational motifs $(42,43)$. This general model could explain a number of pathogenesis-related observations and cellular events associated with clinical manifestations. It identifies and pinpoints the key element in the successful persistence of the virus which appears to be nothing less than the actual cell attachment process itself. Additional information is, therefore, required on the mechanistic features between viral and cell components in this process.

\section{HIV-1 cell attachment and entry process}

Despite the large volume of information on $\mathrm{T}$ cell depletion, many questions remain unanswered, particularly concerning the specific interactions between HIV-encoded proteins and cell receptors that alter the physiological cell death mechanisms (18). These interactions are clearly implicated in an elaborate process of cell attachment and entry. The process involves essentially three steps: viral cell attachment, co-receptor binding, and fusion of the viral envelope components with the host plasma membrane (26).

The first step is aimed at recognizing the 'correct' target cell. This is achieved by the interaction of viral envelope glycoprotein gp120 with host cell CD4 molecules. It involves several conserved gp120 residues, mainly at domain IV, binding to the second complementarity-determining region of CD4 $(44,45)$.

The gp120 - CD4 interaction is not sufficient for cell entry but it causes conformational changes in the gp120 variable loop regions $\mathrm{V} 1 / \mathrm{V} 2$ and $\mathrm{V} 3$, causing V3 to evaginate and become exposed to host cell co-receptors (46-48). Thus, the second step essentially comprises V3 interacting with the major co-receptors CCR5 or CXCR4.

The V3 - co-receptor interaction leads to further conformational changes in gp120 and dissociation of gp41 from gp120.
Gp41 unfolds and a hydrophobic fusion peptide from gp41 is inserted into the host cell membrane (49-51), thus allowing the final fusion step to take place (reviewed in ref. 26).

Of the three stages, the final fusion step has already been exploited therapeutically, and also several strategies are under development for prophylactic vaccines that aim to block the first step (52-54). From a biological point of view, the second step, that of co-receptor usage, could be considered as a potential therapeutic target although inference of the physiological function of these chemokine receptors by attempting to block viral access may be detrimental, and therefore toxic to the patient.

\section{Is HIV-1 cell attachment facilitated by immuno-viral synapses?}

The organization of a polarized supra molecular structure by the retrovirus human T lymphotropic virus type 1 (HTLV-1) to facilitate transmission between $\mathrm{T}$ cells has been described (55). This structure was designated a virological or viral synapse because of similarities to the immunological synapse. HIV-1 infective particles are also reported to be released at cell-to-cell contact sites (56), probably utilizing virological or infectious synapse structures between antigen presenting cells and $\mathrm{T}$ cells (57). This synapse-directed viral transfer model offers several functional advantages for the virus such as increasing the probability of reaching target cells, concentrating viral receptors at sites of contact, activating the target $T$ cell for an efficient viral replication, and protecting the virus from immune recognition (57). Viral attachment and conjugation, however, need stable and prolonged interactions with the target cell. The infectivity of virus particles away from the infected cell after budding is greatly diminished suggesting that the dynamic forces of a virological synapse are probably not sufficient to maintain the attachment of the virus long enough. Such stable interactions can be provided by the immunological synapse. The virus can potentially exploit the contact between the antigen presenting macrophage and the responding $\mathrm{CD}^{+}{ }^{+} \mathrm{T}$ cell by incorporating the gp120/gp41 hetero-dimeric trimer structure to the immuno-synaptic site, thus creating an immuno-viral synapse. There are several lines of evidence which could support this hypothesis: i) CD4 molecules can be cross-linked by membrane-bound Env or virions (56); ii) T cell CCR5 is recruited at the immunological synapse during antigen presentation leading to enhanced $\mathrm{T}$ cell activation (58); iii) dimerization of CCR5 invokes Gprotein mediated tyrosine kinase activation and subsequent signaling cascades that affect $\mathrm{T}$ cell function (59); and iv) the semi-conserved domain of the gp120-V3 region incorporated onto the macrophage surface induces an enhanced and accelerated activation in effector/memory $\mathrm{CD} 45 \mathrm{RO}^{+} / \mathrm{CD}^{+} \mathrm{T}$ cells during antigen presentation (38). V3 interacts functionally, at least, with CCR5 $(38,40)$, delivering an ionically-dependent single triggering signal to responding $\mathrm{T}$ cells rather than a repeatable activation signal (39). Interestingly, V3 - CCR5 sulphated N-terminal peptide-peptide interaction studies with surface plasmon resonance showed an optimal complex formation at a molar ratio of 3:2 suggesting that three V3 domains are needed to dimerize CCR5. This may well explain functionally the trimeric nature of the gp120/gp41 complex. 
A

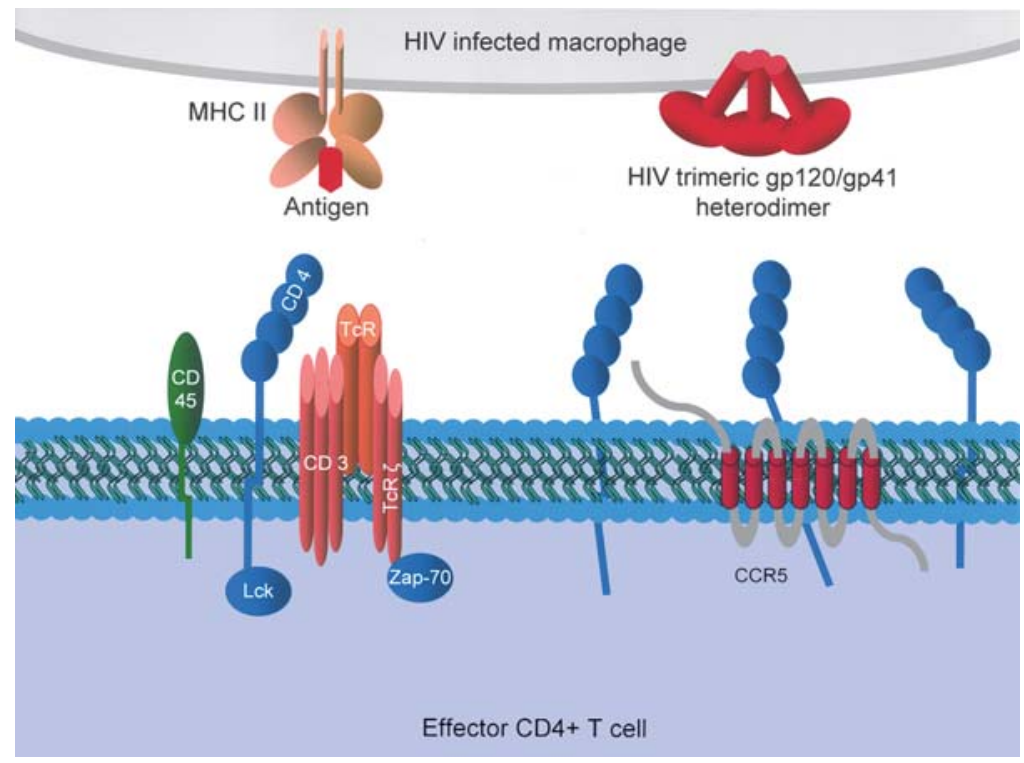

B

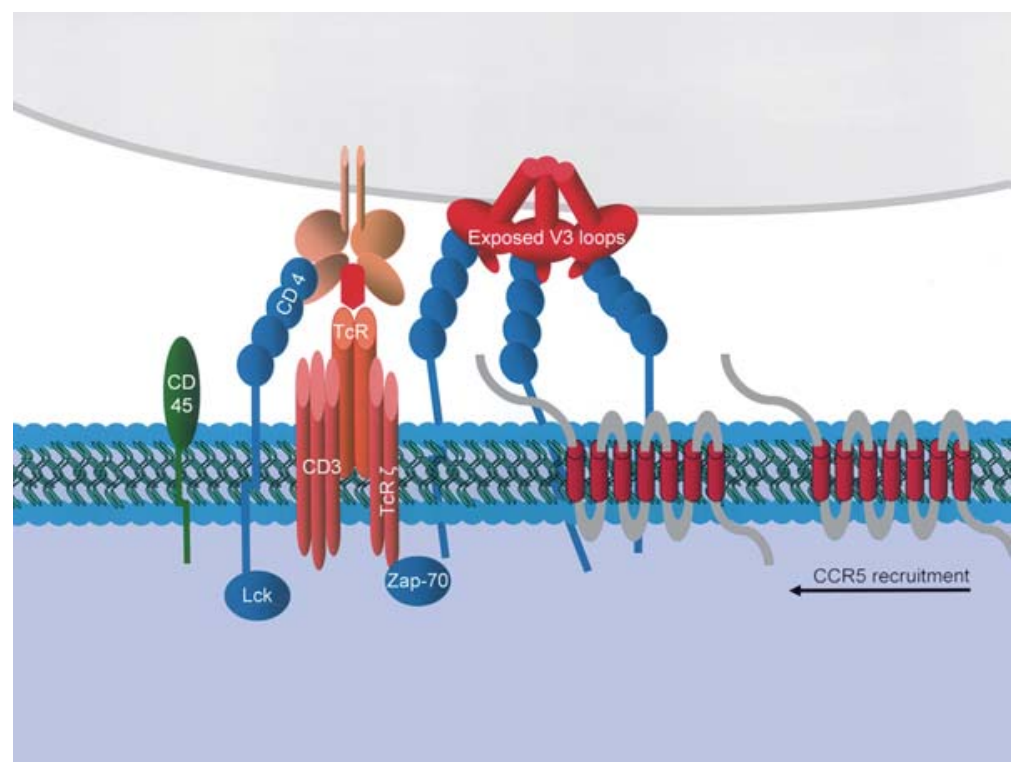

C

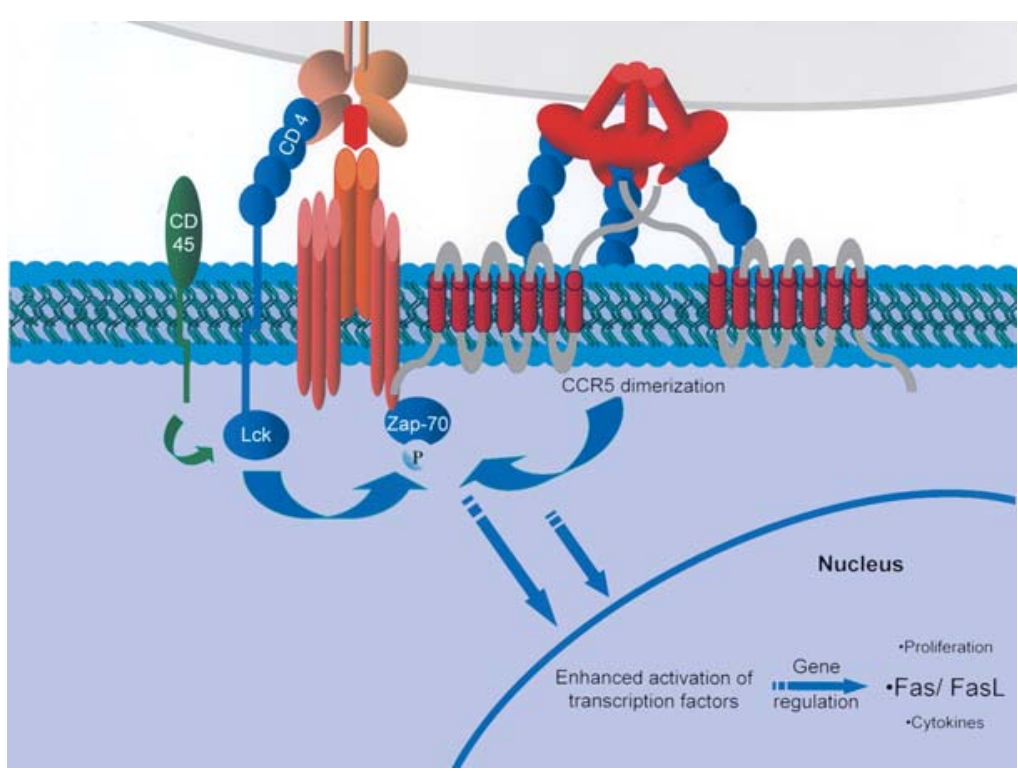

Figure 1. Proposed antigen presentation between an HIV-1-infected macrophage and a responding effector/memory $\mathrm{CD}^{+} \mathrm{T}^{\mathrm{T}}$ cell that leads to enhanced and accelerated T cell activation and death. (A) Participating key surface components at the approach of effector/memory T cell to the HIV-1-infected macrophage. (B) Assembly of an immuno-viral synapse: immune complex formation and gp120-CD4 cross-linking causing conformation changes to gp120 with V3 protruding. (C) Dimerization of recruited CCR5 by three V3 domains triggers signals that contribute to T cell receptor transactivation pathways. 


\section{Proposed theoretical model of R5 HIV-1 cell attachment and concluding remarks}

The asymptomatic phase is perhaps the most critical stage of HIV-1 infection as it causes chronic dysfunction of the immune system. During this phase HIV-1 R5 variants that utilize CCR5 as co-receptor are predominant. CCR5 is present on the surface of macrophages and activated $\mathrm{CD} 45 \mathrm{RO}^{+} / \mathrm{CD}^{+} \mathrm{T}$ cells and is therefore a potential target for the virus. The macrophagetropism of these HIV variants reveals the pattern of infection which resembles the Trojan horse principle. Infected macrophages retain their ability to present antigens. Effector/memory $\mathrm{T}$ cells that respond to the presentation process are engaged to an immune synapse via the $\mathrm{T}$ cell receptor complex. During the assembly of the immune synapse structure, polarization of CCR5 molecules and HIV gp120/gp41 trimeric structures to the site of cell contact leads to a supra molecular immunoviral synaptic complex. At the synapse, gp120 cross-links with $\mathrm{T}$ cell CD4 molecules causing conformational changes to gp120 and thus exposing the V3 region (46). The protruding V3 domains from the viral trimer complex dimerize CCR5 and trigger intracellular signaling which are probably directed to enhance $\mathrm{T}$ cell receptor transactivation pathways that regulate proliferation, cytokine secretion and activation-induced cell death (Fig. 1). This interaction also causes further gp120 conformational changes that lead to the dissociation of gp41 from the hetero-dimeric complex thus allowing the fusion peptide domain of gp41 to attach to the target cell plasma membrane and conjugate (49-51). HIV-1 cell entry is, therefore, a complex, dynamic and multifunctional process prone to incompletion due to viral-induced down-regulation of antigen presentation components in the HIV-infected macrophages. Disruption of the immuno-viral synapse, probably the most common outcome, condemns the engaged $\mathrm{T}$ cells to a premature Fas-FasL-mediated activation-induced cell death (FasL is over-expressed during enhanced $\mathrm{T}$ cell activation). This results in insufficient recovery of memory $\mathrm{T}$ cells to the specific cognate antigen which gradually leads to an accumulated loss of $\mathrm{CD}^{+}{ }^{+} \mathrm{T}$ cell memory. In the case of successful cell entry, the virus possesses several accessory molecular 'tools', such as Nef, to halt the target cell from going to apoptosis and also to evade immune surveillance (42).

In essence, we are proposing a 'kiss of death' functional model of HIV-1 transmission from macrophage to $\mathrm{T}$ cell that may help to explain the observed depletion of uninfected effector/memory $\mathrm{CD}^{+}{ }^{+} \mathrm{T}$ cells that characterizes the asymptomatic phase of the infection. Understanding the assembly, organization and precise function of a potential immuno-viral synapse mediated by R5 HIV-1 may assist in elucidating strategies to combat infection. Interference of in vitro transmission of R5 HIV-1 virions by X4-derived peptides (60) is a hopeful indication in that direction.

\section{Acknowledgements}

We would like to thank Professor Jay Mehrishi for his constructive review of the manuscript. The manuscript is part of a research programme supported by the General Secretariat for Research and Technology, Greece (grant no. 4.5.1-SPYB/31-2003)

\section{References}

1. Barre-Sinoussi F, Chermann JC, Rey F, Nugeyre MT, Chamaret S, Gruest J, Dauguet C, Axler-Blin C, Vezinet-Brun F, Rouzioux C, Rozenbaum W and Montagnier L: Isolation of a T-lymphotropic retrovirus from a patient at risk for acquired immune deficiency syndrome (AIDS). Science 220: 868-871, 1983.

2. Popovic M, Sarngadharan MG, Read E and Gallo RC: Detection, isolation, and continuous production of cytopathic retroviruses (HTLV-III) from patients with AIDS and pre-AIDS. Science 224: 497-500, 1984

3. Dalgleish AG, Beverley PC, Clapham PR, Crawford DH, Greaves MF and Weiss RA: The CD4 (T4) antigen is an essential component of the receptor for the AIDS retrovirus. Nature 312: 763-767, 1984.

4. Klatzmann D, Champagne E, Chamaret S, Gruest J, Guetard D, Hercend T, Gluckman JC and Montagnier L: T-lymphocyte T4 molecule behaves as the receptor for human retrovirus LAV. Nature 312: 767-768, 1984

5. European guidelines for the clinical management and treatment of HIV-infected adults in Europe. AIDS 17 (suppl 2): S3-S26, 2003

6. Lehrman G, Hogue IB, Palmer S, Jennings C, Spina CA, Wiegand A, Landay AL, Coombs RW, Richman DD, Mellors JW, Coffin JM, Bosch RJ and Margolis DM: Depletion of latent HIV-1 infection in vivo: a proof-of-concept study. Lancet 366: 549-555, 2005.

7. Zhu T, Korber BT, Nahmias AJ, Hooper E, Sharp PM and Ho DD: An African HIV-1 sequence from 1959 and implications for the origin of the epidemic. Nature 391: 594-597, 1998.

8. Korber B, Muldoon M, Theiler J, Gao F, Gupta R, Lapedes A, Hahn BH, Wolinsky S and Bhattacharya T: Timing the ancestor of the HIV-1 pandemic strains. Science 288: 1789-1796, 2000.

9. Salemi M, Strimmer K, Hall WW, Duffy M, Delaporte E, Mboup S, Peeters M and Vandamme AM: Dating the common ancestor of SIVcpz and HIV-1 group M and the origin of HIV-1 subtypes using a new method to uncover clock-like molecular evolution. FASEB J 15: 276-278, 2001

10. Sharp PM, Bailes E, Gao F, Beer BE, Hirsch VM and Hahn BH: Origins and evolution of AIDS viruses: estimating the timescale. Biochem Soc Trans 28: 275-282, 2000.

11. Sharp PM: Origins of human virus diversity. Cell 108: 305-312, 2002.

12. Whitaker RE: Re-assessing the virological approach to HIV pathogenesis: can it explain AIDS as an immunological disease? J Theor Biol 187: 45-56, 1997.

13. Weiss RA: How does HIV cause AIDS? Science 260: 1273-1279, 1993.

14. Badley AD, Pilon AA, Landay A and Lynch DH: Mechanisms of HIV-associated lymphocyte apoptosis. Blood 96: 2951-2964, 2000.

15. Wei X, Ghosh SK, Taylor ME, Johnson VA, Emini EA, Deutsch P, Lifson JD, Bonhoeffer S, Nowak MA, Hahn BH, et al: Viral dynamics in human immunodeficiency virus type 1 infection. Nature 373: 117-122, 1995.

16. Anderson RW, Ascher MS and Sheppard HW: Direct HIV cytopathicity cannot account for CD4 decline in AIDS in the presence of homeostasis: a worst-case dynamic analysis. J Acquir Immune Defic Syndr Hum Retrovirol 17: 245-252, 1998.

17. Douek DC, Picker LJ and Koup RA: T cell dynamics in HIV-1 infection. Annu Rev Immunol 21: 265-304, 2003.

18. Roshal M, Zhu Y and Planelles V: Apoptosis in AIDS. Apoptosis 6: 103-116, 2001.

19. Groux H, Torpier G, Monte D, Mouton Y, Capron A and Ameisen JC: Activation-induced death by apoptosis in $\mathrm{CD}^{+} \mathrm{T}$ cells from human immunodeficiency virus-infected asymptomatic individuals. J Exp Med 175: 331-340, 1992.

20. Gougeon ML and Montagnier L: Apoptosis in AIDS. Science 260: 1269-1270, 1993.

21. Wild CT, Shugars DC, Greenwell TK, McDanal CB and Matthews TJ: Peptides corresponding to a predictive alphahelical domain of human immunodeficiency virus type 1 gp41 are potent inhibitors of virus infection. Proc Natl Acad Sci USA 91: 9770-9774, 1994.

22. Lawless MK, Barney S, Guthrie KI, Bucy TB, Petteway SR Jr and Merutka G: HIV-1 membrane fusion mechanism: structural studies of the interactions between biologically-active peptides from gp41. Biochemistry 35: 13697-13708, 1996.

23. Reeves JD and Piefer AJ: Emerging drug targets for antiretroviral therapy. Drugs 65: 1747-1766, 2005. 
24. De Clercq E: Emerging anti-HIV drugs. Expert Opin Emerg Drugs 10: 241-273, 2005.

25. Lazzarin A: Enfuvirtide: the first HIV fusion inhibitor. Expert Opin Pharmacother 6: 453-464, 2005.

26. Krambovitis E, Porichis F and Spandidos DA: HIV entry inhibitors: a new generation of antiretroviral drugs. Acta Pharmacol Sin 26: 1165-1173, 2005.

27. Rusconi S, Scozzafava A, Mastrolorenzo A and Supuran CT: New advances in HIV entry inhibitors development. Curr Drug Targets Infect Disord 4: 339-355, 2004.

28. Greenberg M, Cammack N, Salgo M and Smiley L: HIV fusion and its inhibition in antiretroviral therapy. Rev Med Virol 14: 321-337, 2004.

29. Cooper DA and Lange JM: Peptide inhibitors of virus-cell fusion: enfuvirtide as a case study in clinical discovery and development. Lancet Infect Dis 4: 426-436, 2004.

30. Moore JP: Coreceptors: implications for HIV pathogenesis and therapy. Science 276: 51-52, 1997.

31. Davis CB, Dikic I, Unutmaz D, Hill CM, Arthos J, Siani MA, Thompson DA, Schlessinger J and Littman DR: Signal transduction due to HIV-1 envelope interactions with chemokine receptors CXCR4 or CCR5. J Exp Med 186: 1793-1798, 1997.

32. Berger EA, Doms RW, Fenyo EM, Korber BT, Littman DR, Moore JP, Sattentau QJ, Schuitemaker H, Sodroski J and Weiss RA: A new classification for HIV-1. Nature 391: 240, 1998.

33. Kwa D, Vingerhoed J, Boeser-Nunnink B, Broersen S and Schuitemaker H: Cytopathic effects of non-syncytium-inducing and syncytium-inducing human immunodeficiency virus type 1 variants on different CD4(+)-T-cell subsets are determined only by coreceptor expression. J Virol 75: 10455-10459, 2001.

34. Krzysiek R, Rudent A, Bouchet-Delbos L, Foussat A, Boutillon C, Portier A, Ingrand D, Sereni D, Galanaud P, Grangeot-Keros L and Emilie D: Preferential and persistent depletion of CCR5+ Thelper lymphocytes with nonlymphoid homing potential despite early treatment of primary HIV infection. Blood 98: 3169-3171, 2001.

35. Nardelli B, Gonzalez CJ, Schechter M and Valentine FT: CD4+ blood lymphocytes are rapidly killed in vitro by contact with autologous human immunodeficiency virus-infected cells. Proc Natl Acad Sci USA 92: 7312-7316, 1995.

36. Cottrez F, Manca F, Dalgleish AG, Arenzana-Seisdedos F, Capron A and Groux H: Priming of human CD4+ antigenspecific T cells to undergo apoptosis by HIV-infected monocytes. A two-step mechanism involving the gp120 molecule. J Clin Invest 99: 257-266, 1997.

37. Polyak S, Chen H, Hirsch D, George I, Hershberg R and Sperber K: Impaired class II expression and antigen uptake in monocytic cells after HIV-1 infection. J Immunol 159: 2177-2188, 1997.

38. Zafiropoulos A, Baritaki S, Sioumpara M, Spandidos DA and Krambovitis E: V3 induces in human normal cell populations an accelerated macrophage-mediated proliferation - apoptosis phenomenon of effector $\mathrm{T}$ cells when they respond to their cognate antigen. Biochem Biophys Res Commun 281: 63-70, 2001.

39. Zafiropoulos A, Baritaki S, Vlata Z, Spandidos DA and Krambovitis E: Dys-regulation of effector CD4+ T cell function by the V3 domain of the HIV-1 gp120 during antigen presentation. Biochem Biophys Res Commun 284: 875-879, 2001.

40. Baritaki S, Zafiropoulos A, Sioumpara M, Politis M, Spandidos DA and Krambovitis E: Ionic interaction of the HIV-1 V3 domain with CCR 5 and deregulation of $T$ lymphocyte function. Biochem Biophys Res Commun 298: 574-580, 2002.
41. Cormier EG, and Dragic T: The crown and stem of the V3 loop play distinct roles in human immunodeficiency virus type 1 envelope glycoprotein interactions with the CCR5 coreceptor. J Virol 76: 8953-8957, 2002.

42. Krambovitis E, Zafiropoulos A, Baritaki S and Spandidos DA: Simple electrostatic interaction mechanisms in the service of HIV-1 pathogenesis. Scand J Immunol 59: 231-234, 2004.

43. Galanakis PA, Spyroulias GA, Rizos A, Samolis P and Krambovitis E: Conformational properties of HIV-1 gp120/V3 immunogenic domains. Curr Med Chem 12: 1551-1568, 2005.

44. Olshevsky U, Helseth E, Furman C, Li J, Haseltine W and Sodroski J: Identification of individual human immunodeficiency virus type 1 gp120 amino acids important for CD4 receptor binding. J Virol 64: 5701-5707, 1990.

45. Kwong PD, Wyatt R, Robinson J, Sweet RW, Sodroski J and Hendrickson WA: Structure of an HIV gp120 envelope glycoprotein in complex with the CD4 receptor and a neutralizing human antibody. Nature 393: 648-659, 1998.

46. Sullivan N, Sun Y, Sattentau Q, Thali M, Wu D, Denisova G, Gershoni J, Robinson J, Moore J and Sodroski J: CD4-induced conformational changes in the human immunodeficiency virus type 1 gp120 glycoprotein: consequences for virus entry and neutralization. J Virol 72: 4694-4703, 1998.

47. Kwong PD, Wyatt R, Sattentau QJ, Sodroski J and Hendrickson WA: Oligomeric modeling and electrostatic analysis of the gp120 envelope glycoprotein of human immunodeficiency virus. J Virol 74: 1961-1972, 2000.

48. Moulard M, Lortat-Jacob H, Mondor I, Roca G, Wyatt R, Sodroski J, Zhao L, Olson W, Kwong PD and Sattentau QJ: Selective interactions of polyanions with basic surfaces on human immunodeficiency virus type 1 gp120. J Virol 74: 1948-1960, 2000.

49. Lu M, Blacklow SC and Kim PS: A trimeric structural domain of the HIV-1 transmembrane glycoprotein. Nat Struct Biol 2: 1075-1082, 1995

50. Chen CH, Matthews TJ, McDanal CB, Bolognesi DP and Greenberg ML: A molecular clasp in the human immunodeficiency virus (HIV) type 1 TM protein determines the antiHIV activity of gp41 derivatives: implication for viral fusion. J Virol 69: 3771-3777, 1995.

51. Weissenhorn W, Dessen A, Harrison SC, Skehel JJ and Wiley DC: Atomic structure of the ectodomain from HIV-1 gp41. Nature 387: 426-430, 1997

52. Joseph J, Etcheverry F, Alcami J and Maria GJ: A safe, effective and affordable HIV vaccine - an urgent global need. AIDS Rev 7: 131-138, 2005

53. Slobod KS, Bonsignori M, Brown SA, Zhan X, Stambas J and Hurwitz JL: HIV vaccines: brief review and discussion of future directions. Expert Rev Vaccines 4: 305-313, 2005.

54. Excler JL: AIDS vaccine development: perspectives, challenges and hopes. Indian J Med Res 121: 568-581, 2005.

55. Davis DM, Igakura T, McCann FE, Carlin LM, Andersson K, Vanherberghen B, Sjostrom A, Bangham CR and Hoglund P: The protean immune cell synapse: a supramolecular structure with many functions. Semin Immunol 15: 317-324, 2003.

56. Jolly C, Kashefi K, Hollinshead M and Sattentau QJ: HIV-1 cell to cell transfer across an Env-induced, actin-dependent synapse. J Exp Med 199: 283-293, 2004.

57. Morita E and Sundquist WI: Retrovirus budding. Annu Rev Cell Dev Biol 20: 395-425, 2004.

58. Molon B, Gri G, Bettella M, Gomez-Mouton C, Lanzavecchia A, Martinez AC, Manes S and Viola A: T cell costimulation by chemokine receptors. Nat Immunol 6: 465-471, 2005.

59. Wong MM and Fish EN: Chemokines: attractive mediators of the immune response. Semin Immunol 15: 5-14, 2003.

60. Baritaki S, Dittmar MT, Spandidos DA and Krambovitis E: In vitro inhibition of R5 HIV-1 infectivity by X4 V3-derived synthetic peptides. Int J Mol Med 16: 333-336, 2005. 